\title{
LITERATURA NÃO-CANÔNICA DE DIVULGAÇÃO CIENTÍFICA EM AULAS DE CIÊNCIAS
}

\author{
NON-CANONICAL LITERATURE OF SCIENTIFIC SPREADING OF \\ SCIENCE TEACHING: IN ADDITION TO THE CONTENT OF SCIENCE
}

\author{
Gisnaldo Amorim Pinto*
}

\begin{abstract}
Resumo
Diferenciando a divulgação científica canônica da divulgação científica não canônica, este trabalho realiza uma análise de narrativas presentes em obras não canônicas de literatura, destacando suas potencialidades ao ensino de ciências. Foi possível localizar uma opção narrativa pela imaginação criadora, pela capacidade humana e por sua potencialidade criativa, elementos que são, nesse caso, motes fundamentais para reflexão sobre a vida humana e também sobre a ciência. Em especial na obra Meninos da planície, Cástor Cartelle, 2001, foi possível perceber uma contribuição para renovação do ensino de ciências, pois sua centralidade recai sobre a reflexão acerca da humanização dos sujeitos e não sobre a transmissão de conteúdos da ciência, embora essa dimensão, a da formação científica, esteja inequivocamente presente, sem prejuízos.
\end{abstract}

Palavras-chave: Ensino de ciências. Humanismo. Divulgação científica.

\begin{abstract}
Differing the canonical scientific spreading from the non-canonical scientific spreading, this study makes analysis of the narratives present in non-canonical works of literature. It was possible to localize one narrative option through the creative imagination, the human capacity and its creative potentiality, elements which are, in this case, fundamental motivations for the reflection about human life and also about science. In particular the work Meninos da Planície, Cástor Cartelle, 2001, was possible to suppose a likely contribution to the renewal of science teaching in the selected works, because its centrality remains over the reflection about the humanizing of the subjects and not over the transmission of science contents, although such dimension, the one of scientific formation, is undoubtedly present, without any harm.
\end{abstract}

Keywords: Science teaching. Humanism. Scientific spreading.

\footnotetext{
* Licenciado em Ciências Biológicas pela UFMG; Mestre em Educação pela UFMG; Doutor em Educação pela Universidade de São Paulo. Prof. Adjunto da Universidade Federal de São João Del Rey. E-mail: gisnaldo@ufsj.edu.br
} 


\section{INTRODUÇÃO}

ensa10

Neste trabalho, apresentamos uma breve análise de obras de divulgação científica "não-canônicas" avaliando seu potencial para utilização em aulas de ciências ${ }^{1}$. A categorização utilizada para classificar e selecionar as obras - divulgação científica não canônica - tem relação com o uso de uma linguagem implícita, metafórica e em que estão presentes os conflitos e contradições do fazer científico e da subjetividade humana. Neste sentido, consideram-se obras não canônicas aquelas em que a narrativa volta-se, sobretudo, à compreensão dos processos da ciência, do fazer científico e dos dilemas envolvidos na prática da ciência (compreendida como prática sócio-cultural), diferentemente de obras de divulgação científica cuja centralidade narrativa recai sobre a divulgação de resultados da ciência, os conteúdos científicos e a difusão de uma imagem da ciência como prática de iluminados e vista, em especial, como campo de saber objetivo e consensual. Priorizamos neste artigo a análise das chamadas obras não-canônicas, apresentando uma seleção de obras de divulgação científica, com ênfase na análise dos potenciais reflexivos da ciência especialmente em uma obra, a saber, Meninos da Planície, de Cástor Cartelle, 2001.

A divulgação científica tem encontrado acolhida entre professores de ciências e começa a ser utilizada como motivação tanto para o ensino de conteúdos quanto de processos da ciência. Pesquisas recentes sobre o uso da divulgação científica na sala de aula de ciências apontam tanto as potencialidades do uso da divulgação científica nas aulas de ciências quanto também uma busca, na prática pedagógica de professores de biologia, por novos padrões de linguagem, já que o discurso da ciência pode ser um elemento dificultador para a compreensão da ciência em sala de aula. A pesquisa de Martins, 2005, volta-se à compreensão dos usos da divulgação científica de cunho jornalístico, característico de matérias de divulgação editadas em jornais e revistas. Martins e Damasceno, 2003, analisam a presença - recente - e seus desdobramentos, de textos de divulgação científica em livros didáticos. Segundo os autores, essa presença deve-se tanto à sugestão em documentos oficiais como os Parâmetros Curriculares Nacionais de que se incorporem outros gêneros textuais ao ensino de ciências quanto também a modificações que já estão colocadas nas práticas docentes

\footnotetext{
${ }^{1}$ Este artigo é parte do trabalho de doutorado intitulado Divulgação científica como literatura e o ensino de ciências, Gisnaldo Amorim Pinto, Universidade de São Paulo, 2007.
} 


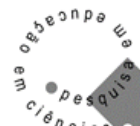 \\ ensa10
}

no que se refere à ampliação do universo de materiais e fontes para o ensino de ciências.

João Zanetic, 1998, oferece interpretação inaugural, em que identifica o potencial para uso na sala de aula de divulgação científica de obras da literatura, como a Montanha Mágica, de Thomas Mann e tratados de ciência como os escritos por Johannes Kepler.

Piassi e Pietrocola, 2007, chamam a atenção para as potencialidades dos usos da ficção científica nas aulas de ciências. Segundo os autores,

\begin{abstract}
a ficção científica vem sendo considerada por diversos autores como um recurso didático no ensino de ciências capaz de despertar o interesse dos estudantes por temas de ciências e facilitar o desenvolvimento de conceitos em sala de aula. Porém, mais do que um recurso didático adicional, a ficção científica deveria ser encarada como um discurso social sobre a ciência que expressa questões, interesses e preocupações atuais a respeito do desenvolvimento científico e tecnológico. (2007, p.1)
\end{abstract}

\section{A DIMENSÃO HUMANA DA DIVULGAÇÃO CIENTÍFICA}

A divulgação científica já foi motivo de interesse de vários pesquisadores. Contudo, foi em Sanchéz Móra que encontramos a categorização que compreende a divulgação científica como literatura. Segundo a autora, “O uso dos recursos literários tem uma finalidade que vai além da simples comunicação de idéias: causar, na maioria das pessoas, uma emoção afetiva ou estética” (2003, p.88). Por meio da análise de clássicos como Stephen Jay Gould, Richard Dawkins, Carl Sagan, Nigel Calder, George Grestein, Sanchéz Mora postula que é possível perceber, na ciência, a dimensão humana - atributo fundamental da literatura.

A autora recortou pequenos trechos de obras de divulgação científica como literatura, trazendo-nos interpretações que demonstram o uso literário da ciência. De acordo com Mora, em $O$ umbigo de Adão, Stephen Jay Gould, a tradição religiosa entrelaçada com a pintura conduz para um argumento de grande peso sobre a criação divina, com aparência de preexistência. São argumentações que, segundo defende a autora, entendem a ciência associada a dimensões metafísicas e religiosas, além de questões ligadas à história e à tradição. 


\title{
Ainda segundo seu ponto de vista, Richard Dawkins, en O gene egoista,
} ilustrar o que são moléculas replicadoras, lança mão da imagem dos copistas da Idade Média. Nesse caso, o divulgador de ciência aborda a biologia molecular por meio da alusão a aspectos históricos e da tradição.

Mora também viu em Carl Sagan, na obra Cosmos, uma boa dose de poesia. Sagan reconheceu que somos feitos de pó estelar e que isso não diminui a grandeza do nosso ser, segundo nos sugere a autora.

Nessa mesma linha, ela localizou em Fred Hoyle, em "Dez faces do Universo", uma postura de "deboche" em relação à cultura classicista, que, para o autor, teria influenciado a descoberta de Maxwell: a noção de éter luminífero, da cultura clássica grega, teria prejudicado a consolidação de uma noção física mais avançada.

Mora entende que os aspectos literários dados ao tratamento da divulgação científica podem ser exemplificados através do uso das seguintes estratégias:

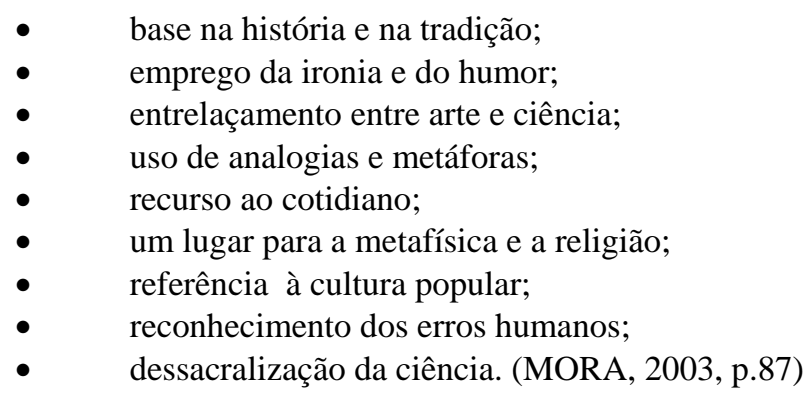

De acordo com a autora, a divulgação da ciência tem tudo para ser prazerosa para o público receptor se, associada à mensagem científica, o tratamento textual for literário:

\begin{abstract}
A divulgação científica como literatura é aquela que emprega recursos literários, a que envolve preocupações humanas, aquela que recria, no sentido de uma expressão pessoal e inovadora. A que não olha para a ciência como conhecimento isolado, mas a submerge no mar das preocupações intelectuais partilhadas pelos seres humanos. (2003, p.109).
\end{abstract}

Sobre o que considera legítima divulgação científica, diz a autora:

(...) no dia em que as antologias literárias incluírem Jay Gould e Sagan, Dawkins e Hoyle, terá sido dado um grande passo na cultura. Se for defendido o valor destas e de muitas outras obras de divulgação científica como literatura, independentemente do tema, estará cimentada uma tradição literária mais flexível e, portanto, mais completa. (2003, p.109). 


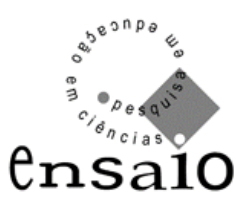

\section{OS CONCEITOS DE CANÔNICA E NÃO CANÔNICA EM OBRAS DE DIVULGAÇÃO CIENTÍFICA}

A divulgação científica que estamos categorizando de “canônica” é aquela cuja linguagem tem atributos particulares. Usamos trechos da obra Cosmos, Carl Sagan, para tentar demonstrar como o conceito de “anã branca” é construído e explicitado. O autor de Cosmos elabora a definição do conceito, partindo do princípio explicativo das reações termonucleares do sol:

(...) Mas a fusão do hidrogênio não pode continuar para sempre; no sol ou em outra estrela, há somente uma determinada quantidade de combustível hidrogênio em seu interior quente. O destino de uma estrela, o final de seu ciclo de vida, depende muito da massa inicial. (1989, p.231)

$\mathrm{Ou}$,

(...) quando o hidrogênio central tiver todo reagido para formar o hélio, daqui a cinco ou seis bilhões de anos, a zona de fusão do hidrogênio migrará lentamente para fora, um recipiente em expansão de reações termonucleares, até atingir o local onde as temperaturas são menores de que dez milhões de graus. A fusão do hidrogênio se encerrará (...) (1989, p.231).

E “(...) a cinza se transformará em combustível e o sol se engajará em um segundo ciclo de reações de fusão” (1989, p.231).

A partir do fato do Sol estar utilizando as cinzas como combustível, Sagan alcança a definição pontual de anã-branca, depois de uma vastíssima argumentação e explicações cada vez mais pormenorizadas:

(...) os restos do Sol, o centro solar exposto, a princípio envolto em sua nebulosa planetária, será uma pequena estrela quente, esfriando no espaço, colapsando em uma densidade jamais imaginada na Terra, mais de uma tonelada em uma colher de chá. Daqui a bilhões de anos o Sol se tornará uma anã-branca degenerada, esfriando como todos os pontos de luz que vemos nos centros das nebulosas planetárias, com temperaturas de superfície altas até o seu último estágio, uma anã-preta, escura e morta. (1989, p.232).

Através destes trechos fica claro que uma obra que chamamos "canônica de divulgação científica”, além de ter os atributos arrolados por Mora, tem também o diferencial da linguagem estritamente explícita. Para o leitor que se debruça sobre obras canônicas, portanto, pouco fica implícito, ou melhor, o autor não pressupõe que 


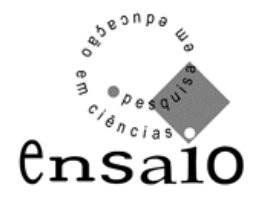

o leitor domine determinados conceitos científicos. Pelo contrário, o autor constrói gradativamente os conceitos, com riqueza de detalhes. Trata-se de explicitações detalhadas e não raramente longas.

Para comparar a idéia de linguagem explícita e implícita, usamos um trecho da obra 2001 - Odisséia no espaço, Arthur Clarke. Clarke também apresenta a definição de anã-branca, mas de maneira muito diferente do que faz um autor como Sagan, numa obra com perfil canônico. O trecho é o que se segue:

(...) O horizonte cada vez mais brilhante, mudou a sua cor de
vermelho escuro para amarelo, depois para azul, e por fim para um
violeta empolado. Arrastando atrás de si erupções periódicas de
matéria estelar, a anã-branca começara a erguer-se no horizonte.
Bowman protegeu os olhos do clarão intolerável do pequeno sol, e
observou o virulento panorama estelar que o seu campo
gravitacional sugava para o céu. Uma vez, nas Caraíbas, fora-lhe
dado contemplar uma tromba d'água em movimento; aquela torre
de chamas tinha quase a mesma forma. Mas a escala era
ligeiramente diferente - a base da coluna devia ser mais larga que o
planeta Terra. (1982, p.189)

A anã-branca na divulgação científica não canônica aparece com o artigo definido fazendo menção a algo já conhecido pelo leitor e que, portanto, não precisaria ser exaustivamente definido pelo autor. A anã-branca então, pela falta de explicitação conceitual, aparece na divulgação científica não-canônica de Clarke como um implícito. O propósito da anã-branca estar presente ao longo da obra é de aludir a uma atmosfera de encantamento e medo. Estes afetos são típicos de um ramo literário mais humanista, cuja utilização poderia se adequar à sala de aula de ciências.

Chamamos a atenção, nesse breve exercício comparativo entre narrativas, para o fato de que a divulgação científica não canônica centraliza o foco da atenção do leitor nas contradições e conflitos existenciais dos personagens, ao passo que a divulgação científica canônica é impessoal e nela não há personagens específicos, com vida própria, recaindo a narrativa sobre os conceitos. Assim, os sujeitos não aparecem, pois o foco é centralizado na divulgação de conceitos e fatos da ciência.

\section{O HUMANISMO E A LITERATURA NÃO CANÔNICA}

Em nosso universo de fontes estão obras que não são comumente tidas como obras clássicas de divulgação científica como literatura. Estão aqui categorizadas 


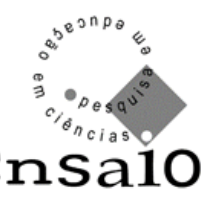

como não canônicas, e têm como centralidade a dimensão da formação humana do leitor/aprendente.

Diferentemente das obras canônicas, que usam da formação humana como mero recurso para se chegar à divulgação de conceitos e dos aspectos estruturais da ciência, as obras não canônicas centralizam o foco na apresentação de aspectos ligados ao desenvolvimento da formação de consciências, o que, em geral, não passa pelo discurso direto da ciência, mas pelo entendimento da dimensão subjetiva, apelando, em alguns casos, para reflexões relativas à dimensão do inconsciente.

A literatura canônica debate a formação humana visando atingir a dimensão conceitual da ciência, enquanto a literatura não-canônica lança mão do discurso da ciência como um artifício para reflexão sobre grandes inquietações da alma humana, no que ela detém de mais subjetivo, também intrinsecamente associado às interações advindas das experiências interacionais. Algumas obras não canônicas selecionadas são também de caráter mitológico, pois exploram aspectos contraditórios e conflitantes da dimensão existencial humana. Chamou-nos atenção particular a abordagem daqueles aspectos subjetivos inerentes à condição humana, que geralmente encontramos na grande literatura de vanguarda. Os conflitos e contradições aparecem numa narrativa de caráter ambivalente, o que caracteriza uma típica narrativa mitológica.

O berço da narrativa mitológica grega nos deixou um legado de mitos, que em geral só existiram para justificar e ordenar o caos da existência humana mediante os dramas e trágicos conflitos que a humanidade e as singularidades humanas tiveram que enfrentar. Resquícios desse modo de narrar a condição humana estão bem caracterizados nas obras de divulgação científica não canônicas.

Então, consultamos desde obras de literatura universal até ficção científica, passando pelos clássicos canônicos de divulgação científica como literatura. Entretanto, elegemos obras “não-canônicas” por terem como diferencial uma narrativa mitológica, em que comparecem conflitos e contradições humanos.

A literatura não canônica tem como perspectiva a existência humana e as relações travadas com os semelhantes no transcurso da vida. O discurso da ciência, assim, assume e requer uma dimensão poética na medida em que "biologia molecular, 


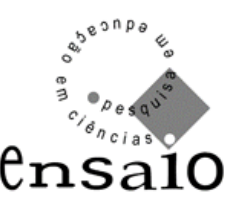

seleção natural, tubos dimensionais e genes” se transformam em mediadores de um caminho de busca de um "si-mesmo"».

\title{
5. A DIVULGAÇÃO CIENTIFICA NÃO CANÔNICA - A SELEÇÃO DAS OBRAS
}

Desejando observar o potencial educacional das obras de divulgação científica, começamos a explorar obras agregadas, por nós, em um segundo grupo. Avaliamos um conjunto de obras como Alice no país do Quantum (1998), O mágico dos quarks (2002), Novas aventuras científicas de Sherlock Holmes (2003), As aventuras científicas de Sherlock Holmes (2002), e Os sonhos atribulados de Maria Luísa (2000). Aliás, todas elas ligadas à física.

Essas obras tecem histórias alegóricas como propósito máximo de ensinar conteúdos da física avançada. A leitura dessas obras permitiu-nos constatar que suas tramas não são envolventes e por vezes há uma certa incompatibilidade no movimento de associação da física com histórias alegóricas. Em meio à aventura de uma criança, por exemplo, aparece um conceito rebuscado de física quântica. Vejamos um trecho de Os sonhos Atribulados de Maria Luisa:

\begin{abstract}
Depois do espanto inicial, começou a achar gozada aquela história de poder existir uma outra Maria Luisa igual a ela, só que de antimatéria. "Se ela tiver idéias opostas às minhas, aposto que não vai passar de ano. Pelo menos em redação. Minha professora disse que eu tenho idéias muito boas e certinhas. Isso quer dizer que as idéias dela devem ser muito más e erradinhas”. Mas a simples hipótese de que uma idéia poderia ser má causou-lhe uma estranha sensação. "Talvez uma idéia sozinha não possa fazer mal algum”, pensou. "Bem, pelo menos não se eu tomar conta dela". (NOVELLO, 2000, p.70-71)
\end{abstract}

Este trecho demonstra que as questões existenciais estão presentes, pois a protagonista experimenta um conflito. Entretanto, a narrativa evolui de forma a não explorar as dimensões do conflito humano. O trecho seguinte já está assim: "Não sei não. Lá em Microlândia nós temos muitas idéias que não servem para nada! Mas nós

\footnotetext{
${ }^{2}$ O conceito de "si-mesmo" pode ser baseado da psicanálise e da psicologia. O "si-mesmo" pode ser entendido à luz da psicanálise como o self, ou seja, uma esfera da consciência humana, onde o sujeito encontra sua essência, segurança, equilíbrio e leveza. O despontar do self na psicanálise implica no final de um processo analítico. Na psicologia analítica o self e o si-mesmo compreendem a manifestação de um estado mais seguro da consciência. Nossa abordagem para o si mesmo não se distancia muito disto, embora não tenhamos a intencionalidade de utilizar categorias da psicanálise.
} 


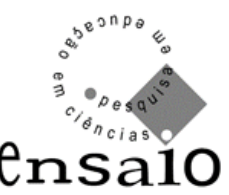

sabemos como elas devem ser tratadas! Era seu velho conhecido, o Píon carregado" (NOVELLO, 2000, p.70-71).

"Microlândia”, "Píon carregado” e outras entidades da ciência aparecem como que por passe de mágica. O leitor fica sem saber se começou mais um sonho de Maria Luísa ou não. O conflito entre bem e mal - que começou a aparecer na narrativa - fica de lado, em detrimento do surgimento de entidades "estranhas” da ciência.

Faltam duas coisas que estão presentes em outras obras selecionadas por nós. A primeira diz respeito ao tratamento dos sonhos, cenário em que se desenvolvem as narrativas de Os Sonhos atribulados de Maria Luísa. Os sonhos nesse livro figuram como pressupostos para ensino de entidades da ciência. Diferentemente, encontramos em Meninos da Planície (cuja trama também se desenvolve através de uma série de sonhos) uma narrativa envolvendo experiências oníricas que aparece com outra coloração para o entendimento do leitor mais jovem. Os sonhos, embora proporcionem o entendimento de entidades da ciência, dizem respeito aos dilemas do cientista, aos conflitos advindos do enfrentamento de situações metafísicas em meio ao exercício da prática científica. De fato, atrai muito a atenção do público leitor, pois humaniza a ciência, convidando à reflexão sobre aspectos inexplicáveis, desconhecidos e eminentemente humanos do fazer científico.

A segunda questão a ser discutida em relação ao livro Sonhos atribulados de Maria Luísa é algo elaborado por Ogborn e outros (1998), que é a construção de entidades da ciência. A maneira como os Píons carregados aparecem na narrativa não vem precedida de uma cuidadosa menção à dimensão das coisas conhecidas. No máximo ocorre uma discreta analogia com pessoas, o que não é tão poético como o realiza Arthur Clarke (1982), por exemplo, ao comparar uma supernova com uma “tromba d’água no mar das caraíbas”.

A seqüência narrativa da obra, portanto, privilegia os fatos da ciência, sem uma ligação efetiva com os fatos da experiência existencial vivida pela protagonista. A vida humana, no que ela tem de inquietudes, como, por exemplo, a ambivalência entre bem e mal, alegria e tristeza - temáticas que comparecem à obra, não é explorada de fato. O resultado é uma narrativa desconexa, em que os fatos da vida cotidiana dos personagens não são associados aos conteúdos da ciência. Com freqüência os capítulos não se conectam com outros e não há, por exemplo, uma seqüência narrativa que possa prender a atenção do leitor a fatos do dia-a-dia. Cada 


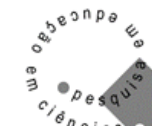 \\ ensa10}

capítulo tem o seu contexto cotidiano diferente. No início de cada capítulo as circunstâncias cotidianas mudam e não há relação acurada com o capítulo precedente nem com o posterior.

Dessa maneira, o que acaba se destacando na obra são os conteúdos de física avançada. Há uma tentativa de apresentação da física avançada pela apresentação da vida cotidiana.

Destacamos obras desse gênero, pois entendemos que o requisito de uso educacional exigiria da narrativa um maior envolvimento com os dramas da existência humana. Conquanto várias obras de divulgação tenham como foco os conflitos humanos, optamos por selecionar aquelas com conteúdo de ciência menos explicitamente rigorosos. Entretanto, resolvemos não trabalhar com essas obras também porque os conteúdos de física quântica nos pareceram muito tecnicamente exigentes.

Avaliamos a produção de ficção científica disponível em português e começamos a encontrar outras obras com o perfil requerido. Algumas obras de ficção científica são povoadas por implicações existenciais, como ocorre em 2001 - odisséia no espaço, Arthur Clark e em Contato, Carl Sagan, obras com linguagem científica mais condensada e implícita, e também com abordagem substancial de experiências existenciais.

\subsection{Breves comentários sobre as quatro obras selecionadas}

Como este artigo é parte de um trabalho mais amplo, em que selecionamos e analisamos quatro obras de divulgação científica não-canônicas, convém que explicitemos de forma sumária uma apreciação sobre as quatro obras escolhidas, para que o leitor perceba que nossas escolhas recaem sobre obras não canônicas de divulgação científica.

Em 2001 - odisséia no espaço percebe-se linguagem implícita no que toca à abordagem de conteúdos de ciências. Os conteúdos de ciência são muito condensados. A centralidade da narrativa recai sobre aspectos existenciais, especialmente do final do livro. Contudo, esta é uma obra que, apesar de selecionada por nós, tem uma grande parte narrada em circunstâncias monótonas, como é a descrição da viagem da 


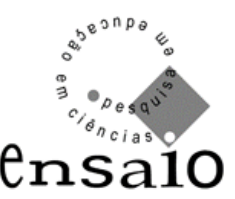

nave Discovery até a chegada a Saturno, onde, de fato, as coisas interessantes acontecem.

Contato já não preenche totalmente este requisito da linguagem implícita, tão cara às obras não canônicas de divulgação científica como literatura. Há descrições muito detalhadas de aparatos tecnológicos e entidades da ciência. A descrição, por exemplo, dos aspectos funcionais e estruturais de um radiotelescópio é muito explícita e detalhista. Entretanto, os conflitos existenciais, presentes ao longo da obra, permitem-nos refletir, por exemplo, sobre os dramas de ser cientista. Uma obra de uma dimensão humanística muito forte, com incursão pelo terreno dos dramas existenciais. Contudo, também essa obra pode pecar pelo excessivo rigor descritivo de artefatos da ciência e da tecnologia, para uma obra que recomendamos ser explorada nas aulas de ciências. Nesse sentido, tanto em 2001- Odisséia no espaço quanto em Contato, selecionamos trechos em que suas narrativas contemplam os requisitos já indicados pela análise e seleção.

Em Meninos da Planície, Cástor Cartelle, a linguagem é implícita no que se refere aos conteúdos da ciência, tornando a obra, de certa forma, prazerosa e pouco cansativa para um leitor juvenil. Os conflitos e contradições não são tão evidentes, mas são suficientes para introduzir o leitor no universo da imaginação científica. O universo onírico se combina muito bem com os planos de descoberta dos cientistas, apresentando possibilidades de leitura que levem aos terrenos da imaginação e criatividade científica. Trata-se de uma narrativa feita aos moldes de um público alvo infanto-juvenil ${ }^{3}$.

Em O Dilema do Bicho-pau, Ângelo Machado teceu uma narrativa absolutamente direcionada ao público infantil, e o próprio título da obra já representa a importância que assumem os conflitos e dramas existenciais. Os conteúdos da ciência são bem implícitos e condensados. Talvez seja a obra que mais se ajusta aos nossos critérios de seleção, com conteúdos implícitos e não descritivos em demasia e alusão aos planos existenciais da vida humana.

\subsection{Os meninos da planície, Cástor Cartelle: um exercício de análise}

\footnotetext{
3 Temos notícias de utilização da obra em escolas da rede particular de ensino de Belo Horizonte e região metropolitana, com bastante recorrência em algumas escolas nos últimos anos, o que nos indica para uma apreciação de sua qualidade e adequação ao ensino de ciências.
} 


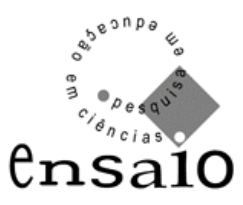

A obra Os meninos da planície - histórias de um Brasil Antigo, do cientista e paleontólogo Cástor Cartelle, versa sobre a pesquisa de um arqueopaleontólogo como artífice de um difícil trabalho de "remontagem” de um passado remoto. A obra está organizada através de uma seqüência de sonhos do personagem que encarna o arqueólogo. A partir das descrições oníricas e revelações dos sonhos do arqueólogo, o outro personagem cognominado "seu amigo" vai descobrindo as relações entre os conteúdos dos sonhos revelados e a prática científica de descoberta. Os sonhos são sempre premonitórios e reveladores de enigmas que povoam a subjetividade do cientista. Os conflitos do cientista não aparecem na obra com contornos tão bem delimitados pela narrativa, como ocorre nas outras obras que analisamos. Entretanto, a incursão pelo terreno dos sonhos demonstra um pertencimento ao terreno do conflitante e do contraditório, na medida em que o sonhar implica na vivência de memórias pessoais passadas e presentes em constante estado de resignificação. A natureza do sonhar é conflituosa à condição humana, pois os sonhos desenterram dramas pessoais da vida pregressa e futura. Há uma riqueza de marcações simbólicas na narrativa onírica do cientista que é interpretada à luz do pensamento científico, marcando um trânsito entre o mundo da imaginação científica influenciado pelas experiências pessoais subjetivas.

A narrativa se desdobra numa trajetória em que o autor estabelece uma ordem linear entre sonhos e a realidade do trabalho do cientista. Fica uma nítida intervenção epistemológica em relação à natureza da ciência relacionada à prática do cientista. Ou melhor, o autor concebe a forma pela qual se dá a prática cotidiana do trabalho de um cientista. Porém, na introdução do livro há explícitas menções referentes à natureza da ciência, quais sejam:

(...) As histórias imaginadas neste livro pretendem despertar o interesse por um tempo quase perdido na distância. Há nele enorme riqueza que pouco se ressalta em nossa história oficial e que nossos arqueólogos resgatam com trabalho paciente. (...) Era arqueólogo e estava estudando os materiais que retirara durante a escavação feita num terreno ao longo de um paredão calcáreo e dentro de uma gruta. Grande parte do que estava no laboratório era resultado de anos de duro e contínuo trabalho. Com suas pesquisas, aos poucos, ia trazendo de volta um passado remoto. (CARTELLE, 2001, p.6-8) 


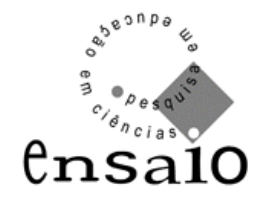

Nesses trechos ${ }^{4}$, a impressão deixada é de que o autor concebe a natureza da ciência em questão, (no caso a paleoarqueologia), como remontadora de um passado remoto. Nesse sentido, percebe-se uma visão de ciência próxima daquela que ainda está muito arraigada nos meios escolares, de uma ciência muito positivista, no sentido de portadora de uma prática irrefutável, contrariando os princípios da refutabilidade de verdades (POPPER, 1973). O sentido positivista de ciência, vista como uma prática que por ser baseada em experimentos e fatos (nessa acepção, irrefutável), fica evidenciada no pequeno trecho em que o autor afirma que: “Com suas pesquisas, aos poucos, ia trazendo de volta um passado remoto".

Entendemos que uma crença exagerada no poder explicativo da ciência, nesse caso, na paleoarqueologia, como remontagem verdadeira do passado, possa ser amortecida através de referências à imprecisão e à incompletude dos dados e resultados de pesquisa. Entretanto, isso não ocorreu.

Os trechos parecem traduzir uma imagem de ciência bem próxima do modelo baconiano de ciência, no qual a experiência científica, mediada pelas ações dos cientistas na procura de verdades, seria suficiente para garantia e irretocabilidade dessas mesmas verdades. Muito próximo, nesse caso, do sonho baconiano de uma sociedade controlada pelos propósitos científicos em busca do bem comum.

Se o trabalho do cientista implicou uma atividade experimental, na qual a remontagem de peças de um quebra-cabeça histórico se efetiva, seria esse movimento algo suficiente para garantir o estatuto de credibilidade inviolável do conhecimento aludido. Nesse sentido, é uma imagem muito positiva da ciência, na medida das suas possibilidades.

Estas impressões introdutórias sobre a natureza da ciência se chocam com a seqüência da obra. Entendemos ter havido um suposto conflito entre a concepção de ciência exposta na introdução e as concepções no decorrer da obra. Entretanto, isso nos pareceu intencional e salutar, na medida em que uma concepção positivista de natureza da ciência foi amortecida e equilibrada por uma visão de natureza da ciência baseada nas experiências cotidianas dos cientistas, através da narrativa surpreendente e humanizadora da discussão sobre natureza da ciência.

\footnotetext{
${ }^{4}$ A avaliação destes curtos trechos é devida a uma espécie de "crença” que o autor revelou no começo do livro: "Com suas pesquisas, aos poucos, ia trazendo de volta um passado remoto" (CARTELLE, 2001, p.8).
} 


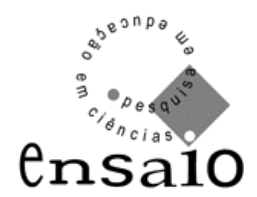

A obra apresenta trechos em negrito em que estão narrados "fatos" oníricos e trechos em itálico em que são narrados fatos do cotidiano dos personagens. Neste ponto nos é útil o conceito de "transformação do conhecimento" (OGBORN, J. et al. 1998). Se admitirmos que o autor explicitou sua preferência por uma concepção de natureza da ciência na introdução da obra, não é difícil percebermos como a visão epistemológica do autor, no bojo da obra, torna-se diferente.

Ocorreu uma transformação das concepções canônicas até que o autor chegasse a conceber uma abordagem epistemológica presente na literatura de divulgação científica.

Vejamos os trechos logo a seguir: (...) Num dos braços havia uma cicatriz com a forma de um trevo. Usava um colar de sementes vermelhas e pretas e, no braço esquerdo, onde estava a cicatriz, um bracelete adornado com pequenos dentes de macaco. (CARTELLE, 2001, p.12)

Neste primeiro trecho, aparece a descrição de um sonho que o paleoarqueólogo havia experimentado antes de efetivar uma descoberta.

No trecho a seguir, o cientista se depara com seus trabalhos cotidianos dentro do laboratório com os artefatos obtidos dos campos empíricos:

(...) Meu amigo acordou assustado. Em sua mesa de estudos havia uma caixa com sementes furadas pretas e vermelhas, e fitas de fibras, nas quais haviam sido fixados alguns dentes de animais como macacos, porcos-do-mato, veados... pegou a caixa onde colocava o esqueleto da menina e começou a examinar o crânio. (CARTELLE, 2001, p.12)

No trecho abaixo o cientista descobre, surpreendentemente, que as evidências experimentais que tinha guardavam relações com seus sonhos premonitórios:

(...) Traduzo agora umas linhas da carta. Após relatar as análises que fizeram e escrever sobre problemas de herança, concluíam: “Os exames do fragmento de osso pertencente ao esqueleto AU indicam que o referido esqueleto é do sexo masculino, enquanto o esqueleto NI é do sexo feminino. Os testes realizados levam a concluir que os dois eram irmãos”. Era quase inacreditável. (CARTELLE, 2001, p.12)

Estes trechos apontam para uma imagem da prática científica pouco convencional nos meios acadêmicos. A idéia de que um cientista possa ter revelações oníricas premonitórias em sua prática cotidiana não é nem um pouco acadêmica. 


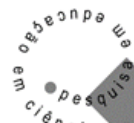 \\ ensa10}

Há autores que apontam para a presença da irracionalidade na ciência (GRANGER, 1994; JAPIASSU, 1996). Há outros como Holton (1989) e Bronowski (1983) que, embora explorem as dimensões da imaginação científica, o fazem de forma a admitir o papel da intuição e do imponderável. Estes autores traçam perfis de cognição dos cientistas de forma coerente, o que não implica a reprodução do que ocorre na prática, principalmente sócio-política, das academias. Nenhum cientista arriscaria a fundamentar suas conclusões com base em experiências oníricas, pois não encontraria nenhum respaldo entre seus pares. Isso não significa que no plano da subjetividade experiencial do cientista os sonhos não possam ter apresentado grandes evidências reveladoras de verdades científicas. Tão marcante é o caso bem conhecido dos relatos na história da ciência dos sonhos antecipados de Kekulé com uma cobra mordendo o próprio rabo nas imediações da proposição do anel de benzeno!

Há uma diferença marcante entre as concepções epistemológicas anunciadas na introdução da obra pelo autor cientista e as concepções exibidas no decorrer da obra. Neste sentido a narrativa exibe um conflito entre a proposta inicial e o conteúdo da obra.

O autor é surpreendente, pois arquitetou uma narrativa cheia de imaginação e sonhos, que não costumam participar de reflexões mais acadêmicas na prática científica, nem na apresentação que se faz das ciências na Educação Básica.

A transformação de uma concepção de ciência arcaica para uma outra mais ligada ao cotidiano pareceu-nos bem marcante em Os meninos da planície. A obra revela-nos um personagem cientista mergulhado numa atmosfera de conflitos pessoais que o aproximam de um cidadão leigo, que precisa tomar decisões importantes em sua vida. Assim, os conflitos e as contradições delimitam um interesse efetivado por nós pela obra, pois a ciência narrada por Cartelle retira o cientista da perspectiva estritamente acadêmica e racional e trás a imagem de um sujeito portador de sonhos e subjetividade.

É um recado humanizador da prática científica, em que salta aos olhos a imaginação e a criatividade como dimensões de uma subjetividade muitas vezes alheia aos tratados filosóficos de ciência.

\section{CONSIDERAÇÕES FINAIS}




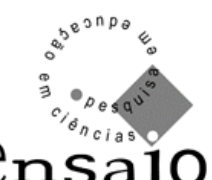

As obras selecionadas suscitam novas potencialidades para o ensino de ciências, na medida em que apresentam aspectos diferentes daqueles tradicionalmente encontrados tanto na literatura didática convencional quanto comumente na literatura de divulgação científica canônica, tais como:

a) ênfase em aspectos processuais da ciência e não nos resultados da ciência;

b) reflexões sobre a existência humana e suas contradições;

c) priorização do prazer pela leitura, com ênfase em aspectos literários e ficcionais. Nesse caso, conquanto consideremos que todas as obras analisadas tenham rigor científico e apresentem aspectos inequívocos da ciência e da tecnologia, em todas elas o gosto pela literatura - o prazer nisso implicado - norteia as narrativas, dando-lhes o tom;

d) centralidade na reflexão sobre a humanização e não na transmissão de conteúdos da ciência, embora esses também compareçam às obras, sem prejuízos;

e) reflexão sobre a condição humana do cientista, apresentado como um sujeito inserido no mundo e numa teia de relações sociais, políticas e afetivas;

f) presença de contradições e do imponderável;

g) presença de reflexões sobre a ambivalência dos personagens, favorecendo um convite ao leitor para reflexão sobre sua própria condição humana também inevitavelmente ambivalente;

h) imbricamento entre ficção e realidade em benefício da beleza literária e do prazer pela leitura;

i) indicação de que a imaginação criadora, a capacidade humana e a potencialidade criativa são motes fundamentais para reflexão sobre a ciência, uma ciência compreendida como fazer e não como resultado verdadeiro, pronto e irrefutável;

j) presença de narrativas mitológicas, em que estão presentes as contradições, os sonhos e os conflitos humanos como indicativos de descoberta do simesmo e do sentido da existência humana. Nesse caso, nas obras analisadas a compreensão do si-mesmo é a centralidade e a narrativa dos processos e resultados da ciência acontece na medida de sua potencialidade para reflexão sobre a existência humana e seus impasses; 


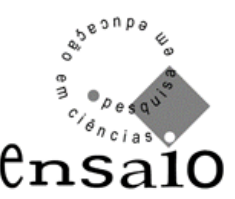

k) ênfase em situações conflitantes, como, por exemplo, situações em que as contradições entre o medo e o encanto, desejo e possibilidade e sonho e experiência não são incomuns.

Poesia, ficção e mitologia... ambigüidade, ambivalência e imponderável podem povoar o universo de aprendizagem de ciências, sem o que teremos ensinado uma ciência feita de conteúdos assépticos, uma ciência que não é feita por pessoas reais e que, por isso mesmo, não é compreendida como criação humana e, portanto, é vista pelos sujeitos de maneira descolada do universo social, político e cultural em que ela é feita.

Despedimo-nos do leitor com um depoimento-poema escrito por um garoto e reproduzido por Carl Sagan em Contato:

Meu coração vacila como uma folhinha.
Os planetas rodopiam em meus sonhos.
As estrelas assediam minha janela.
Giro em meu sonho.
Minha cama é um planeta quente ${ }^{5}$.

\section{REFERÊNCIAS BIBLIOGRÁFICAS}

BRONOWSKI, Jacob. A escalada do homem. São Paulo: Martins Fontes, 1983.

GRANGER, Gilles-Gaston. A ciência e as ciências. São Paulo: UNESP, 1994.

HOLTON, Gerald. La imaginación científica. México: Fondo de Cultura Económica, 1989.

JAPIASSU, Hilton. A crise da razão e do saber objetivo: as ondas do irracional. São Paulo: Letras \& Letras, 1996.

MARTINS, Isabel; DAMASCENO, Allan R. Uma análise das incorporações de textos de divulgação científica em livros didáticos de ciências. Anais do VIII Encontro de Pesquisa em Ensino de Física, 2003. Disponível em: http://www.sbf1.sbfisica.org.br/eventos/epef/viii/PDFs/CO18_1.pdf Acesso em: 06/09/2008.

MARTINS, Isabel.; NASCIMENTO, Tatiana G.; ABREU, Teo B. Clonagem na sala de aula: um exemplo do uso didático de um texto de divulgação científica.

\footnotetext{
${ }^{5}$ Marvin Mercer, Escola pública 153, quinto grau, Harlem, Nova York, 1981, APUD SAGAN, 1997.
} 


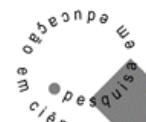 \\ ensa10}

Investigações em ensino de Ciências. Rio Grande do Sul, v.9, n.1, jul 2004. Disponível em: http://www.if.ufrgs.br/public/ensino/vol9/n1/vol9_n1_a4;htm. Acessado em: 09/04/2005.

MORA, Ana Maria Sánchez. A divulgação da ciência como literatura. Rio de Janeiro: Casa da Ciência/ UFRJ, 2003.

OGBORN, J. et al. Formas de explicar. La enseñanza de las ciencias en secundaria. Madrid: Santillana, 1998.

PINTO, Gisnaldo Amorim. Divulgação científica como literatura e o ensino de ciências. 2007. 225f. Tese (Doutorado em Ensino de Ciências) - Faculdade de Educação, Universidade de São Paulo, São Paulo, 2007.

POPPER, Karl. La logica de la investigación científica. Madrid: Tecnos, 1973.

ZANETIC, João. Física e arte: uma ponte entre duas culturas. Pro-Posições, v.17, n.1, p.39-57, jan./abr. 2006.

\section{OBRAS DE DIVULGAÇÃO CIENTÍFICA}

BRUCE, Colin. As aventuras científicas de Sherlock Holmes - o paradoxo de Einstein e outros mistérios. Rio de Janeiro: Jorge Zahar, 2002.

Novas aventuras científicas de Sherlock Holmes - casos de lógica, matemática e probabilidade. Rio de Janeiro: Jorge Zahar, 2003.

CARTELLE, Castor. Os meninos da planície - histórias de um Brasil antigo. Belo Horizonte: Formato, 2001.

CLARKE, Arthur. 2001 - odisséia no espaço. Portugal: Europa-América, 1982.

GILMORE, Robert. Alice no país do quantum: uma alegoria da física quântica. Rio de Janeiro: Jorge Zahar, 1998.

O mágico dos Quarks - a física de partículas ao alcance de todos. Rio de Janeiro: Jorge Zahar, 2002.

MACHADO, Ângelo. O dilema do bicho-pau. Rio de Janeiro: Nova Fronteira, 1997.

MANN, Thomas. A montanha mágica. Rio de Janeiro: Nova Fronteira, 2000.

NOVELLO, Mário. Os sonhos atribulados de Maria Luísa: uma alegoria da cosmologia e da física. Rio de Janeiro: Jorge Zahar, 2000. 


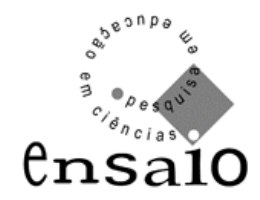

SAGAN, Carl. Contato: romance. São Paulo: Companhia das Letras, 1999.

Cosmos. Editora Vila Rica, 1992.

Data de recebimento: 09/10/08

Data de aprovação: 25/07/09

Data de versão final: 05/10/09 